\title{
Anticipating the Use of Hebrew Script in the LC/NACO Authority File
}

\section{By Heidi Lerner}

The North American library community is looking at ways to enhance authority records with nonroman scripts. The Library of Congress Name Authority Cooperative Program (NACO) Authority File (LC/NAF) is limited to Latin script. This paper looks ahead to the use of other scripts in LC/NAF. The author examines the options for using Hebrew script in MARC 21 authority records, and considers the prospects for cooperative authority work between American and Israeli libraries.

A uthority control is time-consuming and labor-intensive, but is a crucial A aspect of bibliographic control. National and international standards for machine-readable cataloging (MARC) permit nonroman scripts to be used in authority records. The creation of multiscript name authority records for the Library of Congress Name Authority Cooperative Program (NACO) Authority File (LC/NAF) by catalogers at the Library of Congress (LC) and NACO participants has been deferred until all LC/NAF's partner sites support the same scripts. The principles and guidelines that determine when and what kind of nonroman script headings or references to add to name authority records (NARs) remain unresolved.

This paper introduces the background and use of nonroman scripts in MARC and the current practices for providing Hebrew script access points (personal names, corporate body names, and uniform titles) in bibliographic records in the Research Libraries Group (RLG) Union catalog. The author looks ahead to when Hebrew and other nonroman scripts can be used in NARs that are contributed to LC/NAF. The options for using Hebrew script in MARC 21 authority records are examined. The prospects for the creation of a Hebrew authority file and its possible link to LC/NAF and cooperative authority work between American libraries and libraries in Israel are considered.

Heidi Lerner (lerner@stanford.edu) is Hebraica/Judaica Cataloger, Stanford University Libraries, Palo Alto, Calif.

This paper grew out of a presentation given at the 2005 Annual Convention of the Association of Jewish Libraries, Oakland, Calif., on June 21, 2005.

The author thanks Patrick Lo (Lingnan University Library, Hong Kong), Tatyana Parshina and Elena Zagorskaya (Russian National Library, St. Petersburg), Seth Jerchower and Arthur Kiron (University of Pennsylvania Libraries), and especially Joan Aliprand (formerly of the Research Libraries Group) for the very valuable and generous help, suggestions, and examples that were received during the writing of this paper.

\section{Background MARC Formats}

The MARC format became available for bibliographic records in $1968 .{ }^{1}$ The North American library community also has used the MARC format as the standard for organizing authority information up to the present. Institutions share and acquire this information, thus avoiding duplication of effort and creating records that are predictable and reliable.

LC issued a preliminary edition of a MARC format for authorities in $1976 .{ }^{2}$ Authorities: A MARC Format, 1st ed. followed in $1981 .^{3}$ The USMARC Format for Authority Data superseded the first edition in $1987 .{ }^{4}$ MARC 21, the most upto-date version of the MARC formats, appeared in 1999, following the harmoni- 
zation of the Canadian Marc (CAN/MARC) and USMARC formats. ${ }^{5}$ The MARC 21 Format for Authority Data replicates features of the MARC 21 Format for Bibliographic Data that are used for nonroman script data in bibliographic records. ${ }^{6}$

UNIMARC, a set of formats for machine-readable data published by the International Federation of Library Associations and Institutions (IFLA), includes a format for authority records. More than one established heading in different scripts may reside in a single record, or they may exist in parallel, linked records. The second option is analogous to the use of 7XX fields in MARC $21 .^{7}$

\section{Hebrew and Other Nonroman Script Implementation in Library Systems}

The first implementation of nonroman scripts in machinereadable bibliographic and authority records was in Israel. In 1981, the Automated Library Expandable Program (ALEPH) system, utilizing locally developed software, implemented both roman and Hebrew scripts in its library network. The system also offered authority file to bibliographic file linkage. ${ }^{8}$

The 1980s witnessed advances in technology that led to the implementation of nonroman scripts for use in the online catalog in the United States; RLG added the capability to encode Hebrew script to its bibliographic database, then known as RLIN, in 1988. ${ }^{9}$

Presently, the RLG Union Catalog contains almost half a million catalog records in Hebrew-script languages, with approximately half of these containing Hebrew script data. ${ }^{10}$ The OCLC Online Computer Library Center (OCLC) recently introduced Hebrew, Greek, and Cyrillic scripts in its WorldCat bibliographic database with the Connexion client. ${ }^{11}$ The database has almost 65,000 records in its database containing Arabic script. ${ }^{12}$ LC has converted its MUMS library system, which did not display nonroman scripts to Voyager software. $^{13}$

\section{The LC/NACO Authority File}

LC/NAF resides at the Library of Congress with copies maintained by OCLC, RLG, and the British Library, the other LC/NAF partner sites (distribution recipients). ${ }^{14}$ LC/NAF records are restricted to Latin script. Including Hebrew and other nonroman scripts in LC/NAF records can only take place when LC and other LC/NAF partner sites all have the same script capability. Very soon, all LC/ NAF partner sites will have compatible capacities for nonroman scripts. ${ }^{15}$

\section{Cataloging Standards and Principles}

Catalogers at LC, members of the NACO Hebraica Funnel project (a group of libraries that have joined together to contribute name authority records to the national authority file), and other Hebraica catalogers who contribute to LC/NAF have been involved in establishing Hebrew and Yiddish names and titles in this authority file for more than ten years. ${ }^{16}$ LC/NAF headings are established according to the Anglo-American Cataloguing Rules, 2nd ed., 2002 rev. (AACR2), Library of Congress Rule Interpretations (LCRIs), MARC 21 Authority Format for Authority Data, and Public Section Z1 of the Descriptive Cataloging Manual (DCM Z1). ${ }^{17}$ Headings for people, places, and so on, with Hebrew script names, are romanized in conformance with the various rules and practices prescribed in the tools mentioned above, Paul Maher's guide for cataloging Hebraica materials, and LC. ${ }^{18}$

Functional Requirements for Authority Records: A Conceptual Model (FRAR) was recently issued by IFLA for review by the library community. ${ }^{19}$ Language and script are included as attributes for some of the entities defined in the FRAR document. Section 6.5 provides definitions and examples for parallel language and alternate script relationships between access points.

\section{Models for Multiscript Records in the MARC 21 Authority Format}

The MARC 21 Format for Authority Data describes two models, A and B, for multiscript records. ${ }^{20}$ In Model A, nonroman data appears only in 880 fields. The MARC 21 Format for Authority Data defines the 880 field as containing "the fully-content designated representation, in a different script, of another field in the same record., ${ }^{, 21}$ Subfield 6 is used to link a regular field containing the romanized form with its equivalent 880 field, containing the original script. The variety of romanization schemes and nonroman forms of Hebraica names in authority records make a one-to-one linkage between regular and 800 fields impossible. ${ }^{22}$ In Model B, a single heading is created for the name using the language and script determined by the source of authority used to establish the heading. Cross-references can be in any language, written in the appropriate script.

LC guidelines in the MARC 21 Format for Authority Data prohibit LC and NACO catalogers from using 880 fields for alternate graphic representation in name or series authority records that are contributed to LC/NAF; the inclusion of nonroman scripts in the LC/NAF is under investigation by LC. ${ }^{23}$ Between 1980 and 2004, a series of LC and American Library Association (ALA) Machine-Readable Bibliographic Information Committee (MARBI) discussion papers and proposals analyzed and proposed options and characteristics of multiscript headings that could potentially be recorded in authority records. ${ }^{24}$ 
Established 7xx fields are available in MARC 21 to link LC/NAF headings to alternative authorized forms that reside in other authority files, thesauri, or lists. The use of this field in LC/NAF is limited to "records created by National Bibliographic Agencies (NBA) and under certain conditions by designated NACO contributors authorized by the NBA from within the same geographic jurisdiction, for the sole purpose of recording the form of heading used in its national bibliography." ${ }^{\prime 25}$ Contributors to LC/NAF should consult the LC Cooperative Cataloging Team before including $7 \mathrm{xx}$ fields in NARs.

In 2001, MARBI Discussion Paper 2001-DP05 proposed Model C, an alternative to Models A and B for authority records. ${ }^{26}$ This model is based on the concept of a "context marker." The follow-up discussion paper has not yet been released. The cataloging community has not contributed comments on this discussion paper to the MARC Forum electronic discussion group since January $2002 .{ }^{27}$

\section{Literature Review}

The demand for authorized name headings to be established in the language and script in which they are written is growing exponentially. The literature on nonroman scripts and authority control reflects the technological evolution that has occurred since the 1970s. Relevant articles cover the implementation of Hebrew script capabilities in library systems, cataloging with Hebrew script in the online environment, and aspects of the orthographic, romanization, and bibliographic complexities of languages written in Hebrew script.

Tillett provided a state-of-the-art overview of international work on authority control, including the Virtual International Authority File (VIAF) in $2004 .{ }^{28}$ Her presentation included an outline of LC planning for the use of all scripts as well as a discussion of how VIAF relates to the Semantic Web. ${ }^{29}$ Tillett and Plassard presented papers on earlier international and European work. ${ }^{30}$

Weinberg provided an historic and theoretic overview of Hebraica authority work in general. ${ }^{31}$ Katchen described Hebraica authority control in manual-card and automated environments at Brandeis University through the early 1990s. ${ }^{32}$ Simon described the introduction of NACO into Hebrew cataloging operations at Princeton. ${ }^{33}$ Lazinger and Adler presented the issues facing catalogers of items published in Hebrew script. ${ }^{34}$ They exhaustively described and compared American and Israeli cataloging practices of Hebraica material.

Administrators and librarians need to evaluate the tradeoffs between benefits and their cost, when deciding on whether or not to add nonroman scripts to bibliographic records. Lerner summarized the issues involved and the choices that American libraries made about including Hebrew script in catalog records. ${ }^{35}$

Weinberg and Aliprand examined the issue of a single, multilayered authority record versus multiple records in a multilingual/multiscript environment, and concluded that the IFLA model of multiple authority records for a single entity is correct. ${ }^{36}$ Aliprand examined the relationship between scripts and languages with respect to authority control, and concluded that language (as embodied in the rules used to establish headings) is a more important feature of authority records than script. ${ }^{37}$ Examples in these papers show that the complex data relationships in authority records prevent linking of nonroman data with its romanized equivalent(s). Willer and Plassard described how UNIMARC handles relationships between different languages and scripts of headings, and the principles behind the most recent edition of the UNIMARC authority format. ${ }^{38}$

Aliprand has written numerous and significant articles on nonroman character sets and their integration into library systems. Her presentation on true scripts in library catalogs included a discussion on multiscript authority records. ${ }^{39}$ She rigorously examined field linkage in authority records in an earlier paper, and showed that 880 fields (that contain nonroman data) should not be linked to romanized equivalents. ${ }^{40}$ Katchen had independently reached this conclusion empirically. ${ }^{41}$

The use of Unicode in library records has been gradually progressing. In the first paper on this topic, Aliprand began with a critique of romanization. ${ }^{42}$ She later discussed the impact of the use of Unicode on international cataloging. ${ }^{43}$ Vernon wrote on the use of romanization for Hebrew and Arabic script cataloging. ${ }^{44}$ Levi and Lazinger profiled automated authority control in Israel in a series of articles about the ALEPH system published between 1984 and 1996. ${ }^{45}$ Aliprand described the addition of Hebrew script to RLIN. ${ }^{46}$

\section{Current Practices for Adding Hebrew Script Access Points in the RLG Union Catalog Standards}

North American libraries do not follow any prescribed guidelines or standards for authority control for Hebrew and Yiddish names in Hebrew script. An author's name, corporate body name, or uniform title can appear in the RLG Union Catalog in Hebrew script under many different forms. Most catalog records found in local databases or the RLG Union Catalog either have romanized headings that are from $\mathrm{LC} / \mathrm{NAF}$, or have been created in accordance with AACR2. The most successful searching results occur when patrons look for records using romanized headings rather than using nonstandardized Hebrew-script access points. 


\section{Survey: Methods}

In February 2005, the author sent a query to several Judaica- and cataloging-related electronic discussion lists to identify academic and research libraries that contribute catalog records with Hebrew script to the RLG Union Catalog. A request asking for the name of the principal or head cataloger of the responding institution's Hebraica cataloging team was included in the message. Responses were received from catalogers representing nineteen libraries, which are listed in appendix A. The author then sent a short survey to the appropriate staff at these nineteen libraries (see appendix B). Fifteen catalogers responded, describing practices at their respective libraries. A summary of the responses is presented in table 1.

\section{Survey: Findings and Analysis}

This survey revealed that only one library does not provide main and added entries in Hebrew script for personal name, corporate body name, and uniform titles. The fourteen remaining libraries have varying practices for the extent of authority work that they do for Hebrew script personal and corporate name, and uniform title main and added entries; and also for which fields they provide Hebrew script data.

A group of six libraries responded that, while they provide some Hebrew script headings for personal and corporate name, and uniform title main and added entries, they do no authority work on these headings. This group noted that, for the most part, they were inconsistent in their choice of form of a particular heading for both original and derived (copy) cataloging. This group usually transcribes the Hebrew script heading as it appears on the chief source of the item being cataloged. They may or may not provide additions to headings (such as fuller forms of the name, Gregorian or Hebrew calendar dates of birth and death in Hebrew characters or arabic numerals, qualifiers, or language of text to Hebrew script access points). Library users looking for bibliographic records via these uncontrolled Hebrew script forms in their local multiscript catalogs will retrieve only those records that contain that form of the heading. Users may have better results searching Hebrew script access points in the RLG Union Catalog. Because of RLG's clustering algorithm, records that cluster together, despite their varying forms of access points, are retrievable within a single search.

Catalogers from eight libraries indicated that they perform varying degrees of authority work for personal names, corporate bodies, or uniform titles (or some combination of these) written in Hebrew script. One respondent explained that, while not all catalogers at his library necessarily provide Hebrew script access points for personal names and corporate bodies in their cataloging of original or derived records, catalogers add Hebrew forms of the names to the local authority file residing in their library's local system and connecting to the catalog. These forms serve as crossreferences and point to the romanized forms from LC/NAF in their local system. These references are added to their local authority records by professional staff and are based on the Hebrew-script forms found on the items being cataloged. The YIVO Library at the Center for Jewish History created a manual multiscript, multilingual authority file that its catalogers continue to use. ${ }^{47}$ Another respondent reported that, while she does provide some authority work for personal and corporate names for originally created and derived records, her institution does not currently maintain either a manual or online authority file for her library.

\section{Hebrew Script in MARC 21 Authority Records}

LC/NAF partners soon will have the capability to include Hebrew and other nonroman scripts in NARs. This is only the first step. Decisions must be made about the content of records. The remainder of this paper addresses this important issue.

Some libraries have already addressed the issue of authority control in multiple languages. Libraries and Archives Canada requires that two authority records be created for headings used as "either main or added entries in records created for Canadiana." ${ }^{48}$ The Hong Kong Chinese
Table 1. Survey responses $(N=15)$

\begin{tabular}{lcc}
\hline Does library: & Yes & No \\
Provide Hebrew script access points (1XX, 7XX) & 14 & 1 \\
Provide Hebrew script fields & & \\
$\quad 100$ & 11 & 4 \\
110 & 11 & 4 \\
130 & 7 & 8 \\
700 & 11 & 4 \\
710 & 11 & 4 \\
730 & 7 & 8 \\
Provide authority work for person names, corporate body names, uniform title & 8 & 7 \\
Establish authorized forms for personal names, corporate bodies, and/or uniform titles* & 2 & 13
\end{tabular}

*Two responses were unclear and are counted as "no." 
Authority (Name) Database includes traditional Chinese headings in related authorized forms as 7XXs in their name authority records, and provides cross-references for variant forms. ${ }^{49}$ The Bibliotheca Alexandrina in Egypt provides romanized forms of Arabic personal names that have been established in Arabic script as $7 \mathrm{XX}$-related authorized headings. ${ }^{50}$

The Hebraica cataloging community in most North American libraries cannot separate itself from LC/NACO workflow. This group establishes headings in Latin script and uses AACR2, LCRIs, MARC 21 Format for Authority Data, and DCM Z1 as its sources of authority. At the very least, all variant names to the established form in the $1 \mathrm{xx}$ field should be treated as cross-references, including those in other scripts. Ideally, this enables a searcher to retrieve, for example, all titles by a particular author regardless of the language and script in which they are searching. LC/NAF, as accessed through LC, OCLC, and RLG, does not support linking cross-references in authority records to established forms in bibliographic records. Many libraries, however, use headings and references from LC/NAF in authority files that reside in their local systems. Some of these files provide automatic authority-to-bibliographic record links.

Figure 1 shows part of the LC/NAF authority record for the author Sholem Aleichem. Figures 2 through 5 present examples of how nonroman scripts potentially can be included in authority records. In figure 1, Latin script is in the 1xx and $4 \mathrm{xx}$ fields, with the nonroman script in a series of 880 fields. The first 880 field cannot be linked to the established heading since there can only be one source of name authority for a 1xx field in a MARC 21 authority record. In this example, it is linked to the fourth cross-reference, which provides ALA/LC systematic romanization for the heading in a Hebrew context. The first 880 field also could be linked to the third cross-reference that represents the ALA/LC systematic romanization for the author's pseudonym in a Yiddish context. In other words, the Hebrew script spelling in the first 880 field is the usual spelling of the author's pseudonym in both a Hebrew language and a standard Yiddish context. This authority record shows that a strict one-to-one linking between a Latin script field and the Hebrew script fields (as occurs in bibliographic records) is impossible in authority records. Aliprand investigated five models of linking that can exist in

\begin{tabular}{|c|c|}
\hline Heading and Cross-References & Type of Heading/Reference \\
\hline 1000 Sholem Aleichem,Sd185\%-1916 & $\begin{array}{l}\text { LCANACO Authorized Heading [pseud. of } \\
\text { Sholem Yakov Rabinowitz - Ency, Judaica] }\end{array}$ \\
\hline 4000 Cholem Aleichem,Sd1859-1916 & French Heading \\
\hline 4000 Sholem Aleykhem,Sd1859-1916 & $\begin{array}{l}\text { ALA/LC Systematic Romanization for } \\
\text { Heading in a Yiddish Context }\end{array}$ \\
\hline 4000 Shalom 'Alekhem,\$d1859-1916 & $\begin{array}{l}\text { ALA/LC Systematic Romanization for } \\
\text { Heading in a Hebrew Context }\end{array}$ \\
\hline 4000 Sholem Aleikhem,\$d1859-1916 & $\begin{array}{l}\text { Russian Heading (ALA/LC Systematic } \\
\text { Romanization) }\end{array}$ \\
\hline
\end{tabular}

Figure 1. LC/NACO authority record for Sholem Aleichem (partial)

\begin{tabular}{|c|c|}
\hline Heading, Cross-References, 880 Fields & Type of Heading/Reference/ 880 Field \\
\hline 1000 Sholem Aleichem,\$d1859-1916 & $\begin{array}{l}\text { LCNACO Authorized Heading [pseud. of } \\
\text { Sholem Yakov Rabinowitz - Ency. Judaica] }\end{array}$ \\
\hline 4000 Cholem Aleichem,Sd1859-1916 & French Form of Heading \\
\hline 400 0 Sholem-Aleikhem,Sd1859-1916 & $\begin{array}{l}\text { Russian Heading (ALA/LC Systematic } \\
\text { Romanization) }\end{array}$ \\
\hline $\begin{array}{l}400 \text { o } \$ 6880-03 \text { SaSholem Aleykhem,Sdi859. } \\
1916\end{array}$ & $\begin{array}{l}\text { Linked AL.ALC Systematic Romanization for } \\
\text { Heading in a Yiddish Context }\end{array}$ \\
\hline $\begin{array}{l}4000 \$ 6880-015 \text { aShalom 'Alekhem,Sa1859. } \\
1916\end{array}$ & $\begin{array}{l}\text { Linked ALALC Systematic Romanization for } \\
\text { Heading in a Hebrew Context }\end{array}$ \\
\hline $\begin{array}{l}400 \text { I \$6880-04SaRabinovits, Shalom.Sd1859. } \\
1916\end{array}$ & $\begin{array}{l}\text { Linked ALA/LC Systenatic Romanization for } \\
\text { Author's Real Name in a Hebrew Context }\end{array}$ \\
\hline 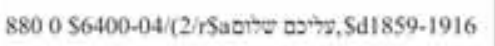 & Linked Hebrew Script Form for $4^{\text {th }}$ Reference \\
\hline $\begin{array}{l}880 \text { o } \$ 6400-02 / \text { (NSalllonem } \\
\text { Aacihxem,Sd1859-1916 }\end{array}$ & Linked Cyrillic Form for $2^{\text {nd }}$ Reference \\
\hline 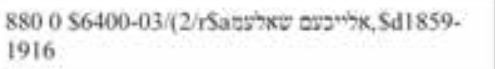 & Linked Soviet Yiddish Form For 3rd Reference \\
\hline 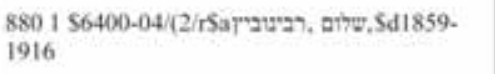 & Linked Hebrew Script Form For $5^{\text {th }}$ Reference \\
\hline 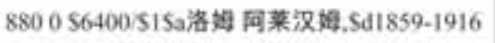 & Unlinked Chinese Form \\
\hline
\end{tabular}

Figure 2. MARC 21 authority format Model A for Sholem Aleichem 
an authority record and rejected them all. ${ }^{51}$ Even if it were possible to pair headings one-to-one in each script, the implementation with complex tagging, field and linking structures would be cumbersome.

Figure 3 shows a Model B record containing the established form for Sholem Aleichem as well as a series of nonroman-script cross-references. A simple, multiscript authority record in which both the roman and script data are stored in regular 1xx and 4xx fields is a much easier solution to put into place. The MARC 21 Format for Authority Data specifies only one authorized heading per record. ${ }^{52}$ The language of the catalog is indicated in the subfield "b" of the MARC 21 tag 040. The heading is formulated according to the MARC 21 Format for Authority Data control field tags 008/08-008/10, which identify the "language of catalog," "kind of record," and the "descriptive cataloging rules" used to formulate the name, name/title, or uniform title in established headings.

In its simplest implementation, multiple script cross-references can be added to existing and new authority records. Source data in the 667-688 note fields can be entered in transliteration or in the true script. Decisions will need to be made on how to handle dates and additions to nonroman script references that contain a term normally given in the language of the cataloging agency. This applies as well to name/title headings and corporate body headings in which the main entry element has been established in the language and script of the catalog. LC/NAF references need to be formulated in accordance with AACR2 and LCRIs guidelines. One alternative, though not the most elegant, is the use of two or more scripts in one reference, seen in the record for Sholem Aleichem's short story, Ṭeyye der milkhiker, in Hebrew (figure 4).

Another solution is to establish headings in one language and its true script(s), and include 7xx linking entry fields for equivalent, established headings in other languages (and their scripts). This model is demonstrated in figure 5 .

Multiple established headings and their accompanying reference (or syndetic) structures cannot be contained in a single authority record. Nonrepeatable data elements in MARC 21 authority records prevent an authority record from being used to establish headings based on alternative sources of authority. In other words, the IFLA model of complementary records in linked language-based authority files should be used. ${ }^{53}$ As described by Weinberg and Aliprand, the library of the YIVO Institute for Jewish Research established separate card catalogs and authority files for authors in Yiddish, Hebrew, Latin, and Cyrillic

\begin{tabular}{|c|c|}
\hline $\begin{array}{l}\text { Heading and Cross-References } \\
\text { (Transliteration and Seripts) }\end{array}$ & Type of Heading/Reference \\
\hline 1000 Sholem Aleichem,Sd1859-1916 & $\begin{array}{l}\text { LCNACO Authorized Heading [pesud. of } \\
\text { Sholem Yakov Rabinowitz Ency. Judaica] }\end{array}$ \\
\hline 4000 Cholem Aleichem,Sd1859-1916 & French Form \\
\hline 4000 Sholem Aleykhem,Sd1859-1916 & $\begin{array}{l}\text { AL.ALLC Systematic Romanization in a } \\
\text { Yiddish Context }\end{array}$ \\
\hline 400 o Shalom 'Alekhem.Sd1859-1916 & $\begin{array}{l}\text { ALALC Systematic Romanization in a } \\
\text { Hebrew Context }\end{array}$ \\
\hline 4001 Rabinevits, Shalom,Sd1859-1916 & $\begin{array}{l}\text { AL.ALC Systematic Romanization for } \\
\text { Authos's Real Name in a Hebrew Context }\end{array}$ \\
\hline 4000 עליכם שלום 0 ,Sd1859-1916 & $\begin{array}{l}\text { Hehrew or Yiddish Form [preferred] of } \\
\text { LC/NACO Authorized Heading }\end{array}$ \\
\hline 400 o Шозем Ахсйхем,Sd1859-1916 & Cyrillic Form \\
\hline 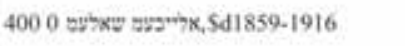 & Soviet Yiddish Form \\
\hline 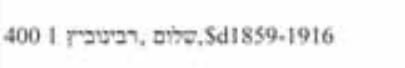 & $\begin{array}{l}\text { Hebrew Script Form of Author's Real Name in } \\
\text { a Hebrew Context }\end{array}$ \\
\hline 4001 1 & $\begin{array}{l}\text { Hebrew Script Form of Author's Real Name in } \\
\text { a Yiddish Context }\end{array}$ \\
\hline 4000 肖洛地 网采汉姢,Sd1859. & Chinese Form \\
\hline
\end{tabular}

Figure 3. MARC 21 authority format Model B for Sholem Aleichem scripts. ${ }^{54}$ Authors who write in more than one language, or whose works appear in translation (or in different scripts) may have up to four separate authority records. Weinberg and Aliprand emphasize that "Another argument against a single composite record with multiple syndetic structures is that it would be more complicated to process and update. ${ }^{~} 55$

If a centralized database of either headings written in the Hebrew language or headings written using the Hebrew script (Hebrew, Yiddish, Ladino, Judeo-Arabic, and so on) were to exist, a bilingual or multilingual library catalog could offer options of invoking Hebrew and English headings for search and display, and linking headings from LC/NAF to alternative authority records with their full reference structures. 


\begin{tabular}{|c|c|}
\hline Heading and Cross-Refereaces & Type of Heading/Refereace \\
\hline $\begin{array}{l}1000 \text { Sholem Aleichem,Sa1859-1916.ST eyye } \\
\text { der milkhiker.SIHebrew }\end{array}$ & $\begin{array}{l}\text { LCNACO Heading for Uniform Titie of Teyye } \\
\text { der milkhiker in Hebrew }\end{array}$ \\
\hline 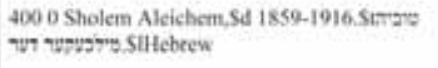 & $\begin{array}{l}\text { Cross-Reference with Original Yiddish Title in } \\
\text { Hebrew Script }\end{array}$ \\
\hline $\begin{array}{l}4000 \text { Sholem Aleichem,Sd1859-916 ST Toviyath } \\
\text { ha-holev }\end{array}$ & $\begin{array}{l}\text { LCINACO Cross-Reference With Romanized } \\
\text { Hetrew Title }\end{array}$ \\
\hline 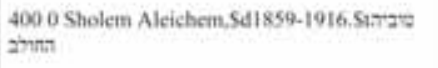 & $\begin{array}{l}\text { Cross-Refertence with Hetrew Title in Hebrew } \\
\text { Script }\end{array}$ \\
\hline
\end{tabular}

Figure 4. Mixed script references for LC/NACO authority record NAFL79119

\begin{tabular}{|c|c|}
\hline Headings, Cross-References & Type of Heading/Reference \\
\hline 1000 Sholem Aleichem Sa1k59-1916 & $\begin{array}{l}\text { LCNACO Authorized Heading (prad. of } \\
\text { Sholem Yaker Rathinowitz - Ency. Judaica) }\end{array}$ \\
\hline 4000 Cholem Aleichem,Sd1859-1916 & French Form \\
\hline 4000 Shoiem Aleykhem,Sd1859-1916 & $\begin{array}{l}\text { ALALC Systematic Romanization in a } \\
\text { Yiddish Contest }\end{array}$ \\
\hline 4000 Rabinovits, Shalom_Sd1859-1916 & $\begin{array}{l}\text { ALANC Systentatic Romanization for } \\
\text { Author's Real Name in a Heberw Comteat }\end{array}$ \\
\hline 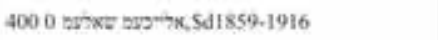 & Soviet Yiddish Form \\
\hline 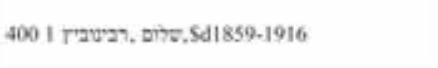 & $\begin{array}{l}\text { Hetrew Seript Form of Auther's Real Narne in } \\
\text { a Hebrew Context }\end{array}$ \\
\hline 400 I raxak, ats.Sd1859-1916 & $\begin{array}{l}\text { Hebrew Script Form of Auther's Real Namse in } \\
\text { a Yiddish Context }\end{array}$ \\
\hline 4000 肖洛姆 同莱设椥.Sdi859-1916 & Chinese Form \\
\hline 70007 Cholem Aleichem (1859.916)S2FrPBN & $\begin{array}{l}\text { Authorized Form From Bibliothique nationale } \\
\text { de Frunce }\end{array}$ \\
\hline 70007 uonom-aneñxeus2RuSpRNB & $\begin{array}{l}\text { Authorized Forn From Russian National } \\
\text { Library }\end{array}$ \\
\hline 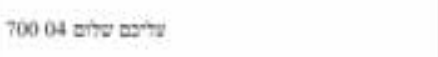 & $\begin{array}{l}\text { Authorized Form From Thesaurus of the Index } \\
\text { to Ifebrew Periodicals }\end{array}$ \\
\hline
\end{tabular}

Figure 5. MARC 21 format authority format Model B with 7xx relator fields

\section{Suggestions for a Hebraic Name Authority File Israeli Sources for Hebraic Headings}

At the present time, no single authoritative source exists for Hebraic language names and titles. Several projects in Israel presently serve as resources for headings. The Institute of Hebrew Bibliography produces the Bibliography of the Hebrew Book 1473-1960. ${ }^{56}$ This bibliography offers authority control in both Hebrew and Latin characters for names and place names, and is under the control of the Jewish National and University Library (JNUL). A subcommittee of JNUL's Standing Committee developed a list of authorized headings in Hebrew for Jewish liturgical and sacred works. This list is available via telnet at an ALEPH Israeli network host site. ${ }^{57}$ The staff at the Index to Hebrew Periodicals maintains an authority file of both persons (as authors and subjects) and generic/ geographic Hebrew subjects. ${ }^{58}$

While many Israeli libraries utilize local authority files, no national or central authority file exists in Israel similar to LC/NAF. Lazinger and Adler reported that Israeli practices for establishing headings differ significantly from American practices, and that Israel still does not follow uniform and definitive cataloging standards and policies. ${ }^{59}$ Different libraries have various solutions for establishing Hebraica names. The variations and complexities of Hebrew orthographies are well documented. Most Israeli institutions normalize headings according to one convention or another, while transcribing the data on the title page in descriptive fields as it appears.

The creation of a Hebraic authority file will depend on a number of issues. Standards and guidelines will need to be investigated and carefully articulated. These will have to reflect the unique characteristics of Hebraica authors, titles, and corporate names.

\section{Cataloging Codes and Reference Tools}

What cataloging codes will be followed? Every authority file specifies a set of descriptive cataloging rules that are used to formulate the 1XX name, name/title, or uniform title heading in established heading or reference records. American catalogers mostly adhere to AACR2. In Israel, Adler, Shichor, and Kedar issued ha-Kițlug: sefer yesodot $u$-khelalim, which presents the principles of AACR2, rearranged and modified for Israeli catalogers of Hebraica materials. ${ }^{60}$ A section of the book matches Hebrew rules with their AACR2 equivalents. However, not every AACR2 rule has a Hebrew equivalent, nor does every Hebrew rule have an AACR2 equivalent (though most of the Hebrew ones do). 
Reference tools need to be identified that serve as required sources of information, or as aids in creating authorized headings and references. These include encyclopedias, dictionaries and lexical tools, encyclopedias, bio-bibliographies, and collective biographies, gazetteers, and other miscellaneous resources.

\section{Other Considerations}

To what orthographic conventions will the file adhere? Will headings be normalized to defective or plene spellings? What guidelines will be developed for treatment of Yiddish orthographic conventions? Specifically, will this file be a language-based or script-based file; that is, should the file have controlled, linked headings for different languages in Hebrew script (such as Yiddish, Ladino and Judeo-Arabic), or will there be a single heading in Hebrew script with crossreferences to the form(s) in the other languages? In Israel, where Hebrew is the dominant language, cross-references could be created from other languages written in Hebrew script. On the other hand, as seen in the YIVO example, Yiddish and Hebrew have equal standing. There is authority control for headings in these languages, as well as for English and Cyrillic (predominantly Russian) headings.

\section{Conclusion}

The addition of nonroman script data in MARC 21 authority records is not far in the future. However, no decisions have yet been made on what these records will look like. LC and NACO members will need to work together and develop guidelines for the implementation of MARC 21 nonroman script data in NARs contributed to LC/NAF.

Adding cross-references is the least expensive and simplest way to add Hebrew script forms to established Hebraica headings in LC/NAF. LC and NACO catalogers can provide these cross-references as they come across them in their cataloging workflow. Eventually these records can be linked to a parallel Hebraic authority file.

Agreeing on national and international standards and guidelines for the structure of multiscript and multilingual authority records is challenging. The intellectual considerations are overwhelming, not to mention the economic. Building and successfully maintaining a Hebraic name authority file will require a collaboration of all of the Judaica and Hebraica cataloging communities in the United States, Israel, Europe, and the rest of the world. These groups will have to work together and share responsibilities for the creation of a Hebraic name authority file. They will then have to prepare for its eventual integration into a larger, international authority file.

\section{References and Notes}

1. Henriette D. Avram, John F. Knapp, and Lucia J. Rather, The MARC II Format: A Communications Format For Bibliographic Data (Washington, D.C.: Information Systems Office, Library of Congress, 1968).

2. Library of Congress, MARC Development Office, Authorities, A MARC Format: Specifications for Magnetic Tapes Containing Authority Records, prelim. ed. (Washington, D.C.: Cataloging Distribution Service, 1976).

3. Library of Congress, Processing Services, Authorities: A MARC Format, 1st ed. (Washington, D.C.: Cataloging Distribution Service, Library of Congress, 1981).

4. Library of Congress, Network Development and MARC Standards Office, USMARC for Authority Data: Including Guidelines for Content Designation (Washington, D.C.: Cataloging Distribution Service, Library of Congress, 1987).

5. Library and Archives Canada, "Implementation of CAN/ MARC-USMARC Harmonization Changes," www.collections canada.ca/6/19/s19-211-e.html (accessed Nov. 25, 2005).

6. Library of Congress, Network Development, and MARC Standards Office, Library of Congress, in cooperation with Standards and Support, National Library of Canada, MARC 21 Format for Authority Data: Including Guidelines for Content Designation (Washington, D.C.: Library of Congress, Cataloging Distribution Service, 1999-).

7. International Federation of Library Associations and Institutions, UNIMARC Manual: Authorities Format, 2nd rev. and enlarged ed., UBCIM Publications, new ser., vol. 22 (Munich: K. G. Saur, 2001), 64-65, www.ifla.org/VI/8/ projects/UNIMARC-AuthoritiesFormat.pdf (accessed Nov. 25, 2005); Library of Congress, MARC 21 Format for Authority Data, Heading Linking Entry Fields (7xx).

8. The Automated Library Expandable Program (ALEPH) was an automated library system that networked the catalogs of twenty-three Israeli libraries. See Judith Levi, "ALEPH: An Online Real-Time Integrated Library System," Judaica Librarianship 1, no. 2 (Spring 1984): 58-63. In its most recent iteration, Ex Libris' ALEPH 500 software incorporates the Unicode Standard. See "Overview," ALEPH Integrated Library System-Ex Libris, www.exlibris-usa.com/aleph.htm (accessed Nov. 25, 2006).

9. Joan M. Aliprand, "Nonroman Scripts in the Bibliographic Environment," Information Technology and Libraries 11, no. 2 (1992): 105-19; John Eilts, "Nonroman Script Materials in North American Libraries: Automation and International Exchange," 61st IFLA General Conference, August 20-25, 1995, Conference Proceedings, www.ifla.org/IV/ifla61/61-eilj .htm (accessed Nov. 25, 2005).

10. "RLG Union Catalog Covers the World," RLG Focus, no. 74 (June 2005), www.rlg.org/en/page.php?Page _ID =20659\#article7 (accessed Aug. 31, 2005); RLG, "Original Scripts in the RLG Databases" (Sept. 26, 2001), www.rlg .org/origscripts.html (accessed Nov. 25, 2005).

11. OCLC, "Past Enhancements to Connexion Client: Hebrew, Cyrillic, and Greek Script Cataloging," www.oclc.org/ connexion/interface/client/enhancements/recent.htm (accessed May 15, 2005). 
12. OCLC, "WorldCat Database Arabic Statistics," www.oclc.org/ worldcat/statistics/arabic_stats.htm (accessed May 15, 2006).

13. The Library of Congress, Integrated Library System Program, "Information for the Public," www.loc.gov/ils (accessed Nov. $25,2005)$.

14. Library of Congress, Program for Cooperative Cataloging, NACO Name Authority Cooperative Program of the PCC, "The NACO FTP Process," www.loc.gov/catdir/pcc/naco/ nodes.html (accessed Nov. 25, 2005).

15. Ed Glazier, "LC/NACO Hubs and Nonroman Scripts," e-mail to author, Aug. 18, 2005; Anne Della Porta, "Planning for Unicode in Libraries: The LC Perspective," Special Library Association Annual Conference, 2005, www.loc .gov/ils/UNICODE/Unicode@SLA.pdf (accessed Nov. 25, 2005); "Unicode Planning and Multi-Script Decisions for Cataloging Policy," LC Cataloging Newsline 12, no. 9 (Aug. 2004), www.loc.gov/catdir/lccn/lccn1209.pdf (accessed Nov. 25, 2006).

16. Rosalie Katchen, "NACO Funnel Projects: The NACO Hebraica Funnel Project," RLIN Focus, no. 12 (Feb. 1995), www.rlg.org/legacy/ftpd/pub/r-focus/12feb95/nacofunn.txt (accessed May 25, 2006).

17. Anglo-American Cataloguing Rules, 2nd ed., 2002 rev. (Ottawa: Canadian Library Assn.; London: Library Assn. Publ.; Chicago: ALA, 2003); Library of Congress Rule Interpretations, 2nd ed. (Washington D.C.: Cataloging Distribution Service, Library of Congress, 1990-); Library of Congress, MARC 21 Format for Authority Data; Library of Congress, Cataloging Policy and Support Office, Descriptive Cataloging Manual: Z1: Name and Series Authority Records, www.loc.gov/catdir/pcc/naco/zl.pdf (accessed May 15, 2006).

18. Paul Maher, Hebraica Cataloging: A Guide to ALA/LC Romanization and Descriptive Cataloging (Washington, D.C.: Cataloging Distribution Service, Library of Congress, 1987).

19. International Federation of Library Associations and Institutions, IV. Division of Bibliographic Control (IV), Working Group on FRANAR, Functional Requirements for Authority Records: A Conceptual Model, Draft (2005-0615), www.ifla.org/VII/d4/FRANAR-Conceptual-M-Draft-e.pdf (accessed May 15, 2006).

20. Library of Congress, MARC 21 Format for Authority Data, Appendix C-Multiscript Records.

21. Library of Congress, MARC 21 Format for Authority Data, Location and Alternate Graphics (8xx), 880-Alternate Graphic Representation.

22. Bella Hass Weinberg and Joan M. Aliprand, "Closing the Circle: Automated Authority Control and the Multiscript YIVO Catalog," International Cataloguing and Bibliographical Control 31, no. 3 (2002): 44-48; Joan M. Aliprand, "Linking of Alternate Graphic Representation in USMARC Authority Records," Cataloging and Classification Quarterly 18, no. 1 (1993): 27-62.

23. Library of Congress, MARC 21 Format for Authority Data: Including Guidelines for Content Designation, Appendix C-Multiscript Records and 880-Alternate Graphic Representation; Barbara B. Tillett, Unicode and Cataloging Policies, e-mail to author, July 12, 2005.
24. For proposals issued 1995 and later, see: Library of Congress, MARC Standards: MARC Proposals, www.loc.gov/marc/ marbi/list-p.html (accessed May 25, 2006); for earlier proposals and discussion papers, see: Library of Congress, Network Development and MARC Standards Office, USMARC Format Proposed Changes (Washington, D.C.: Cataloging Distribution Services, [198?]-).

25. NACO Name Authority Cooperative Program of the PCC, Guidelines for the Use of $7 \times x$ Fields in Name Authority Records, www.loc.gov/catdir/pcc/naco/7xx.html (accessed Nov. 25, 2005).

26. MARBI Multilingual Record Task Force, "Multilingual Authority Records in the MARC 21 Authority Format," MARBI Discussion Paper 2001-DP05, June 8, 2001, www .loc.gov/marc/marbi/2001/2001-dp05.html (accessed May 25, 2006).

27. MARC Forum, www.loc.gov/marc/marcforum.html (accessed Nov. 25, 2005).

28. Barbara B. Tillett, "Authority Control: State of the Art and New Perspectives," Cataloging \& Classification Quarterly 38, no. 3/4 (2004): 23-41.

29. Barbara B. Tillett, "Multi-Script Decisions for Cataloging Policy at the Library of Congress," ALCTS "Library Catalogs and Nonroman Scripts" Program, ALA Annual Conference, Orlando, Fla., 2004, www.ala.org/ala/alcts/alctsconted presentations/Tillett2.pdf (accessed Nov. 25, 2005).

30. Barbara B. Tillett, "Authority Control at the International Level," Library Resources \& Technical Services 4, no. 13 (2000): 168-72; Marie-France Plassard, "Authority Control in an International Environment: UNIMARC Format for Authorities," Workshop on Authority Control among Chinese, Korean, and Japanese Languages held at National Institute of Informatics (NII) in cooperation with National Diet Library, March 28-29, 2001, www.nii.ac.jp/publications/CJK-WS/ 2-1Plassard.pdf (accessed Nov. 25, 2005).

31. Bella Hass Weinberg, "Hebraica Authorities: A HistoricalTheoretical Perspective," Judaica Librarianship 8, no. 1/2 (Spring 1993/Winter 1994): 45-60.

32. Rosalie Katchen, "Hebrew Authority Control at Brandeis," Judaica Librarianship 8, no. 1/2 (Spring 1993/Winter 1994): $56-60$.

33. Rachel Simon, "Contributing Hebrew Name Headings to NACO: A Participant's View,” Judaica Librarianship 8, no. 1/2 (Spring 1993/Winter 1994): 61-68.

34. Susan S. Lazinger and Elhanan Adler, Cataloging Hebrew Materials in the Online Environment: A Comparative Study of American and Israeli Approaches, ed. Sheila S. Inter (Englewood, Colo.: Libraries Unlimited, Inc., 1998).

35. Heidi Lerner, "A Look at Hebraica Cataloging in the United States," Cataloging \& Classification Quarterly 17, no. 1/2 (1993): 115-31.

36. Weinberg and Aliprand, "Closing the Circle."

37. Joan M. Aliprand, "Scripts, Languages, and Authority Control," Library Resources \& Technical Services 49, no. 4 (2005): 243-49.

38. Mirna Willer, "UNIMARC Format for Authority Records: Its Scope and Issues for Authority Control," Cataloging 
\& Classification Quarterly 38, no. 3/4 (2004): 153-84; Plassard, "Authority Control in an International Environment: UNIMARC Format for Authorities."

39. Joan M. Aliprand, "True Scripts in Library Catalogs-The Way Forward," ALCTS "Library Catalogs and Nonroman Scripts" Program, ALA Annual Conference, Orlando, Fla., 2004, www.ala.org/ala/alcts/alctsconted/presentations/Aliprand2.pdf (accessed Nov. 25, 2005).

40. Aliprand, "Linking of Alternate Graphic Representation in USMARC Authority Records."

41. Rosalie Katchen, "Use of Non-Use of Parallel Linking Fields in RLIN for Hebrew-Script Access Points," Judaica Librarianship 8, no. 1/2 (Spring 1993/Winter 1994): 31-32.

42. Aliprand, "Nonroman Scripts in the Bibliographic Environment."

43. Joan M. Aliprand, "The Unicode Standard: Its Scope, Design Principles and Prospects for International Cataloging," Library Resources \& Technical Services 44, no. 13 (2000): $160-67$.

44. Elizabeth Vernon, Decision-Making for Automation: Hebrew and Arabic Script Materials in the Automated Library, Occasional Papers, no. 205 (Champaign, Ill.: Univ. of Illinois, Graduate School of Library and Information Science, 1996).

45. Judith Levi, "ALEPH: An Online Real-Time Integrated Library System”; Susan S. Lazinger, "ALEPH: Israel's Research Library Network: Background, Evolution, and Implications for Networking in a Small Country," Information Technology and Libraries 10, no. 4 (1991): 275-91; Susan S. Lazinger and Judith Levi, "Multiple Scripts in ALEPHIsrael's Research Library Network," Library Hi Tech 14, no. 1 (1996): 111-16.

46. Joan M. Aliprand, "Hebrew on RLIN," Judaica Librarianship 3, no. 1/2 (1986/1987): 5-16; Joan M. Aliprand, "Hebrew on RLIN: An Update," Judaica Librarianship 5, no. 1 (1989/ 1990): 12-20.

47. YIVO Institute for Jewish Research. Library, Der Yidisher $k$ at alog un oyt orit et $n-k$ art ot ek fun der Yivo-bibliot ek, vol. 5, eds. Zachary Baker, Bella Hass Weinberg (Boston: G. K. Hall, 1990),

48. Library and Archives Canada, Cataloguing and Metadata, "Bilingual Cataloging Policy," www.collectionscanada.ca/6/17/ s17-219-e.html (accessed Nov. 25, 2005).

49. Lilly $\mathrm{Hu}$, Owen Tam, and Patrick Lo, "Chinese Name Authority Control in Asia: An Overview." E-LIS: E-Prints in Library and Information Science, 2003, http://eprints.rclis .org/archive/00000301 (accessed May 25, 2006).

50. Iman Khairy, "Authority Control of Arabic Personal Names From the Classical Period at Bibliotehca Alexandrina," MELCOM International 27th Conference, Alexandria, Egypt, May 23-25, 2005, rev. January 2006, http://web.uni-bamberg .de/unibib/melcom/khairy_eng.pdf (accessed May 15, 2006).

51. Aliprand, "Linking of Alternate Graphic Representation in USMARC Authority Records."

52. Library of Congress, MARC 21 Format for Authority Data.

53. Guidelines for Authority Records and References, 2nd ed., rev. by the IFLA Working Group on GARE Revision, UBICM Publication New Series, vol. 23 (Munich: K. G. Saur, 1984), www.ifla.org/VII/s13/garr/garr.pdf (accessed Nov. 25, 2005).

54. Weinberg and Aliprand, "Closing the Circle."

55. Ibid., 45 .

56. Institute of Hebrew Bibliography, Bibliography of the Hebrew Book 1473-1960, www.hebrew-bibliography.com (accessed Nov. 25, 2005).

57. Israeli Inter-University Library Network, "Judaica Uniform Titles," telnet://aleph.huji.ac.i (accessed Nov. 25, 2005); Lazinger and Adler, Cataloging Hebrew Materials in the Online Environment, 79.

58. University of Haifa, Index to Hebrew Periodicals, libnet1 .ac.il/ libnet/ihp/ihp-eng.htm (accessed Nov. 25, 2005).

59. Lazinger and Adler, Cataloging Hebrew Materials in the Online Environment.

60. Elhanan Adler, Aviva Shichor, and Rochelle Kedar, ha-K itl ug: sefer yesodot u-khelalim (Jerusalem: Merkaz ha-hadrakhah lesifriyot tsiburiyot, 1995). 


\section{Appendix A. RLIN Hebrew Script Libraries Surveyed}

Library of Congress ${ }^{*}$

John Rylands Library of the University of Manchester*

New York Public Library*

Yale University Library ${ }^{*}$

University of California, Santa Barbara*

Bodleian Library at Oxford University

Cambridge University Library

YIVO Library from the Center for Jewish History*

University of Pennsylvania Library*

University of Michigan at Ann Arbor Library

Stanford University Libraries

Spertus Institute of Jewish Studies Library*

Yeshiva University Library*

Hebrew College Library*

Library of University of Judaism*

Library of the Jewish Theological Seminary of America*

Klau Library (Library of Hebrew Union College-Jewish Institute of Religion, Cincinnati)*

Frances Henry Library (Hebrew Union College-Jewish Institute of Religion, Los Angeles)

Klau Library (Library of Hebrew Union College-Jewish Institute of Religion, New York)

*indicates respondents to survey 


\section{Appendix B. Hebrew Script Survey}

1. Do you provide main and added entries (100/110/130, 700/710/730 fields) for personal names, corporate body names and/or uniform titles in the Hebrew and Yiddish languages uniform titles in Hebrew script?

Yes No_ (If yes, please continue. If no, stop here.)

2. Please indicate for which fields you provide Hebrew script

100 110 130 700 710 730

3. Do you do authority work for personal names, corporate body names and/or uniform titles written in Hebrew script? Yes No_

(If your answer is "no," please to Section A. If your answer is "yes," please go to Section B.)

\section{Section A: My library does not do authority work for personal names,} corporate body names, and/or uniform titles in Hebrew script.

1. Please explain what principles you follow for personal name main and added entries written in Hebrew script for:

a. Original cataloging

b. Derived cataloging (copy cataloging)

2. Please explain what principles you follow for corporate body name main and added entries written in Hebrew script for:

a. Original cataloging

b. Derived cataloging (copy cataloging)

3. Please explain what principles you follow for uniform title main and added entries written in Hebrew script for:

a. Original cataloging

b. Derived cataloging (copy cataloging)

Section B: My library establishes authorized forms for personal names, corporate body names, and/or uniform titles written in Hebrew script.

1. Please indicate the type of entry for which you establish authorized forms in Hebrew script

Personal names (100 and 700 fields): Yes No

Corporate body names (110 and 710 fields): Yes No

Uniform titles (130 and 730 fields): Yes No

2. Please explain what source of cataloging authority (sources of information, cataloging codes, etc.) you follow to establish these headings (take as much space you need):

3. Does your library or institution maintain a manual or automated authority file? Yes No

4. Where do you use established headings in Hebrew script? (Check all that apply)

Original cataloging

Derived cataloging (copy cataloging) 